Cerebral metabolism and blood flow after circulatory arrest during deep hypothermia. Ann Surg 1972;178:95-101.

56. Hossmann KA, Sato K. Recovery of neuronal function after prolonged cerebral ischemia. Science 1977;168:375-6.

57. Kramer RS, Sanders AP, Lesage AM, Woodhall B, Sealy WC. The effect of profound hypothermia on preservation of cere bral ATP content during circulatory arrest. J Thorac Cardiovasc Surg 1968;56:699-709.

58. Wilson DF, Erecinska M, Drown C, Silver IA. The oxygen dependence of cellular energy metabolism. Arch Biochem Biophys 1979;195:485-93.

59. Bracey VA, Greeley WJ, Greibel JA, Kern FH, Ungerleider JM, Reves JG, Piantadosi CA. Evaluation of brain oxygenation during cardiopulmonary bypass and total circulatory arrest in children by near infrared spectroscopy [Abstract]. Anesthesiology 1990;73:A1109.

60. Kinuta Y, Kikuchi H, Ishikawa M, Hirai O, Imataka K, Koba- yashi S. Reflectance spectrophotometric measurement of in vivo local oxygen consumption in the cerebral cortex. J Cereh Blood Flow Metab 1987:7:592-8.

61. Takagi S, Corito L, Hossmann KA. Blood recirculation and pharmacological responsiveness of the cerebral vasculature following prolonged ischemia of cat brain. Stroke 1977;8:70712.

62. Tanaka J, Shiki K, Asou T, Yasui H, Tokunaga K. Cerebral autoregulation during deep hypothermic nonpulsatile cardiopulmonary bypass with selective cerebral perfusion in dogs. J Thorac Cardiovasc Surg 1988;95:124-32.

63. Heymann MA, Payne BD, Hoffman JIE, Rudolph AM. Blood flow measurements with radionuclide-labeled particles. Prog Cardiovasc Dis 1977;20:55-79.

64. Lacombe P, Meric P, Seylaz J. Validity of cerebral blood flow measurements obtained with quantitative tracer techniques. Brain Res 1980;2:10;-69.

\title{
Directional atherectomy: Combining basic research and intervention
}

\author{
Donald C. MacLeod, MB, ChB, MRCP, ${ }^{a}$ Marcel de Jong, ${ }^{b}$ Victor A. Umans, MD, ${ }^{a}$ \\ Javier Escaned, MD, ${ }^{\mathrm{b}}$ Robert-Jan van Suylen, MD, ${ }^{\mathrm{c}}$ Patrick W. Serruys, MD, PhD, ${ }^{\mathrm{a}}$ \\ and Pim J. de Feyter, MD, $\mathrm{PhD}^{\mathrm{a}}$ Rotterdam, The Netherlands
}

In 1985 Simpson et al. ${ }^{1}$ first described the percutaneous transluminal removal of atheromatous material from peripheral arteries by means of a novel catheter system. The technique was given the term "directional atherectomy," denoting the selective excision of obstructive luminal atheroma to distinguish it from surgical endarterectomy. Initial experience indicated that directional atherectomy could be performed safely and effectively and might be an attractive alternative to conventional balloon angioplasty in certain circumstances. ${ }^{2,3}$ Developments in the atherectomy catheter and the design of suitable

From the ${ }^{\text {aC }}$ ardiac Catheterization Laboratory, Thoraxcenter, and the Departments of ${ }^{b}$ Experimental Cardiology and Pathology, Erasmus University, Rotterdam, The Netherlands.

Received for publication October 21, 1992; accepted December 1, 1992.

Reprint requests: Pim J. de Feyter, MD, PhD, Catheterization Laboratory, Thoraxcenter, Erasmus University, P.O. Box 1738, 3000 DR Rotterdam, The Netherlands.

AM J HEART 1993;125:1748.

Copyright 1993 by Mosby-Year Book, Inc.

$0002-8703 / 93 / \$ 1.00+.10 \quad \mathbf{4} / \mathbf{1} / \mathbf{4 5 6 1 9}$ guiding catheters allowed the extension of the technique to the coronary arteries in $1986 .{ }^{4}$ Recently, directional coronary atherectomy has undergone comparison with coronary balloon angioplasty in a multicenter prospective, randomized trial, the CAVEAT study. After brief discussion of the technical aspects and clinical use of directional atherectomy, this article will focus on the application of atherectomy as a route to research.

\section{TECHNICAL DETAILS}

The Simpson AtheroCath (Devices for Vascular Intervention, Redwood City, Calif.) incorporates a rigid metal cylinder a short distance from the distal tip (Fig. 1). This cylinder is windowed longitudinally on one side and carries an eccentric balloon on the other. Within the cylinder is a cup-shaped cutter that can travel the length of the window; the cutter is advanced and retracted by a hollow drive cable. The most distal part of the cylinder serves as a collection chamber. Proximally, the drive cable connects with a hand-held, battery-operated motor that spins at 


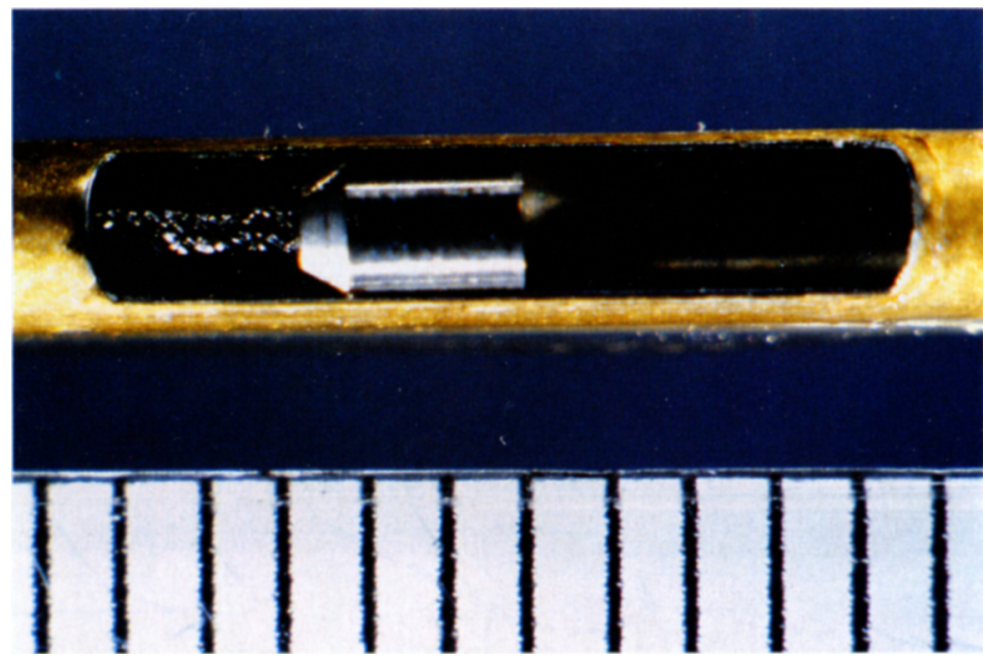

Fig. 1. Simpson Atherocath. In window of cutter housing, cutter and drive cable are visible. Guide wire has been withdrawn. Bar scale, $1 \mathrm{~mm}$.

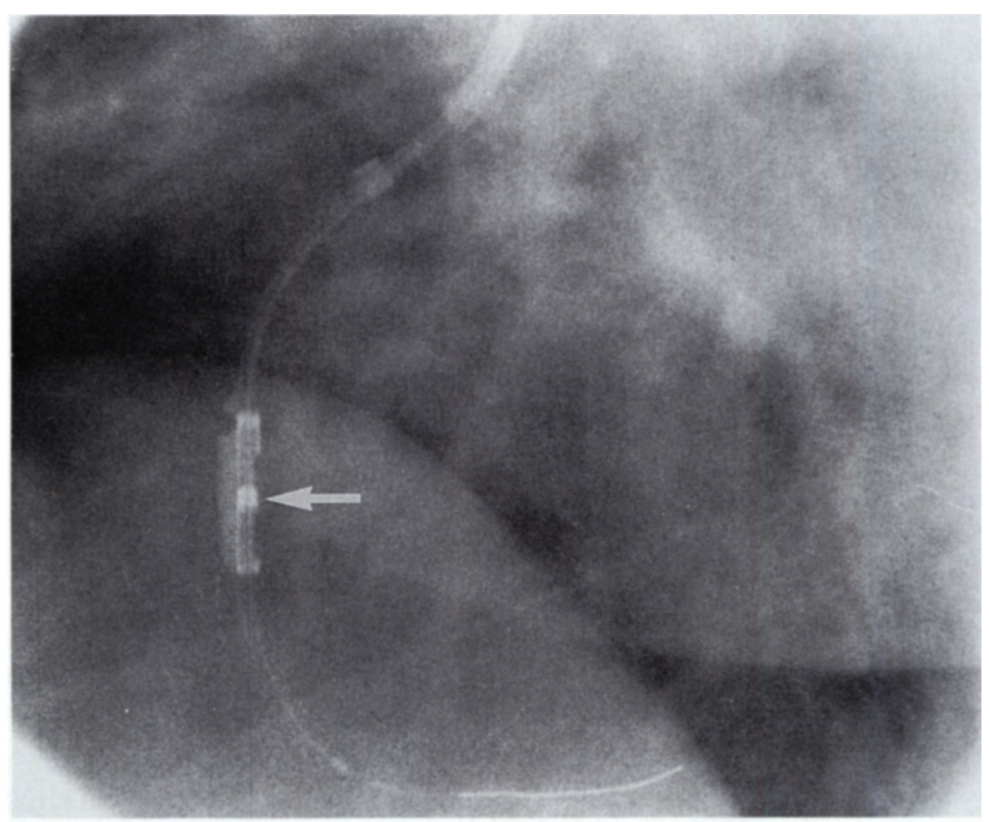

Fig. 2. Directional atherectomy device deployed in right coronary artery, $45^{\circ}$ left anterior oblique projection. Eccentric balloon is inflated with contrast, opposing cutter housing to vessel wall. Rotating cutter is clearly visible (arrow).

$\pm 2,000 \mathrm{rpm}$. To position the Atherocath, a conventional 0.014-inch guide wire is passed through the cable lumen and manipulated across the lesion. The device can then be advanced. For coronary use preshaped, nonangled guiding catheters are first introduced. On retraction of the cutter, low-pressure inflation of the eccentric balloon holds the window firmly against the selected area of atherosclerotic plaque. Material intruding into the window is then shaved off and pushed into the collection chamber by the advancing cutter (Fig. 2). After withdrawal of the device from the patient, specimens are flushed back into the window from where they can be extracted (Fig. 3). The amount of tissue retrieved varies widely but from peripheral lesions approaches $100 \mathrm{mg}$ in weight ${ }^{5}$ and from coronary lesions approximately 20 


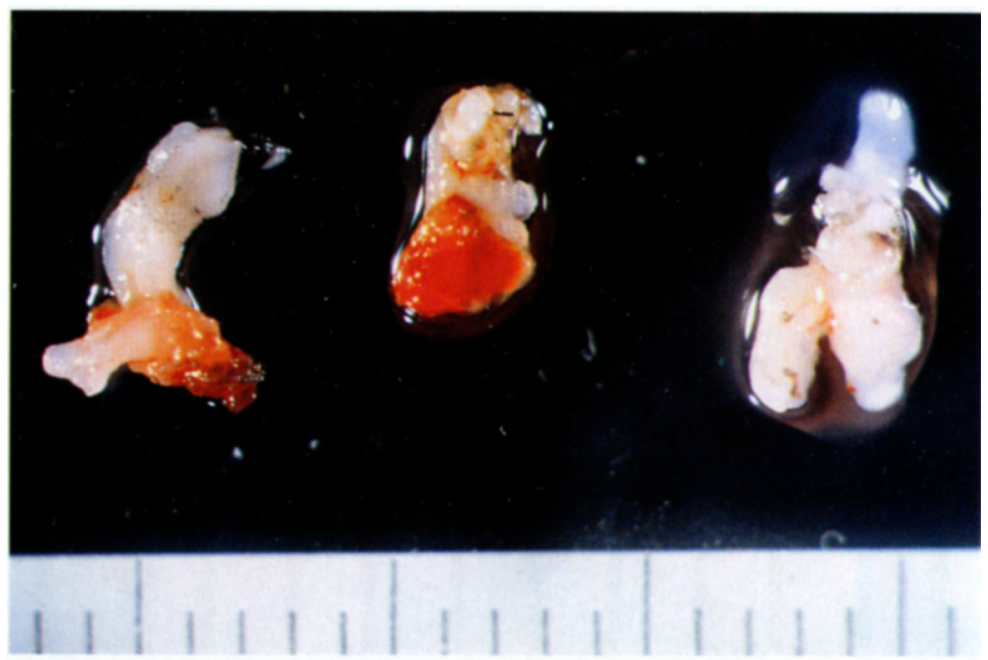

Fig. 3. Macroscopic appearance of tissue retrieved during directional coronary atherectomy. Bar scale, 1 $\mathrm{mm}$.

mg., 5 The rigidity and bulk of the cutting and collection system $(\geq 5 \mathrm{~F})$ limits coronary use to the proximal and middle sections of relatively large vessels $(\geq 2.5 \mathrm{~mm})$; the largest device (11F) may not be sufficient to allow satisfactory apposition in large peripheral arteries.

\section{CLINICAL APPLICATIONS}

There is debate regarding the most appropriate niche for atherectomy in vascular intervention; several reports have focused on the therapeutic potential of the technique in peripheral and coronary arteries. ${ }^{2-4,7,8} \mathrm{It}$ is proposed that atherectomy may be advantageous in dealing with complex lesions often seen in unstable angina, where conventional balloon angioplasty can be associated with suboptimal results. Threatened or abrupt occlusion resulting from balloon-induced dissection can be managed by using directional atherectomy to excise the intimal flap, a bail-out role, but this is controversial. Originally, atherectomy was thought less likely to provoke restenosis on the basis of leaving a smoother vessel lumen with fewer dissections. This is probably not the case, but the increased initial luminal gain compared with conventional balloon angioplasty may better accommodate subsequent restenosis.

\section{RESEARCH APPLICATIONS}

Directional atherectomy has created the potential for new directions in both clinical and laboratory research (Fig. 4). Indeed, among the new interventional devices, atherectomy is unique in providing the means to investigate pathophysiologic phenomena by using human vascular tissue. First, the tissue retrieved by the device can be subjected to histopathologic examination. Traditionally, the pathologic features of atherosclerosis in human beings have been studied by using material excised in the operating theater or autopsy suite. What directional atherectomy now offers is access to fresh vascular tissue for immediate fixation and examination in situations where precise details of the current and previous medical history and clinical investigations are available. Thus histopathologic appearances can be reliably related to different clinical pictures; primary atherosclerosis and restenosis, stable and unstable angina, for example.

Second, this tissue constitutes a source of cells for experimental work. Of necessity, investigations of mechanisms at cellular level in atherosclerosis, restenosis, and acute coronary syndromes have been performed in animal models to date. Studies have identified the vascular smooth-muscle cell as having a pivotal role in the response to injury of the vessel wall. ${ }^{9}$ Smooth-muscle cells disaggregated or cultured from tissue excised at atherectomy can be examined with clectron microscopy to identify subcellular organelles and myofibrils and with immunohistochemistry or electrophoresis to identify cytoskeletal proteins such as smooth muscle cell alpha-actin, to comment on cell phenotype. The distinction between the contractile and synthetic phenotypes of the vascular smooth-muscle cell in culture is shown diagrammatically in Fig. 5. Important behavioral properties of the smooth-muscle cell, migration, proliferation, and extra-cellular matrix synthesis, can be examined in 


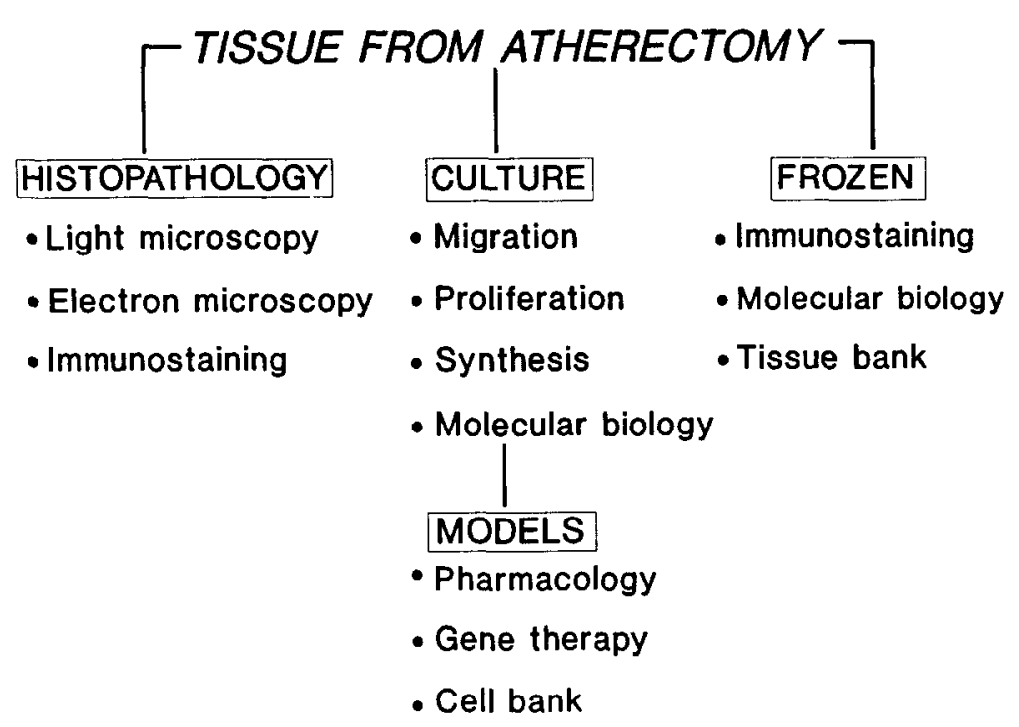

Fig. 4. Directional atherectomy: possible directions of research based on basis of retrieved tissue.

SMOOTH MUSCLE CELL

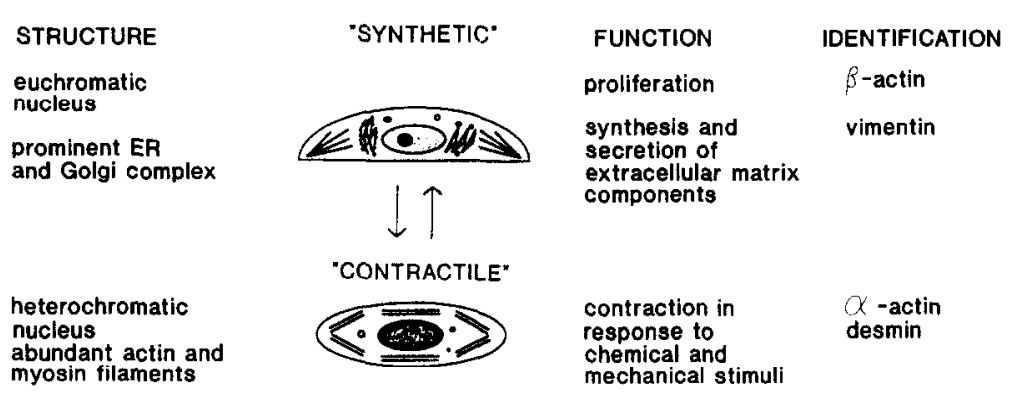

THYBERG; ARTERIOSCLEROSIS 1990

Fig. 5. Diagrammatic representation of differences in smooth-muscle phenotype: synthetic and contractile forms. (Adapted from Thyberg et al. Arteriosclerosis 1990;10:966.)

vitro. Also, cultured human vascular cells may be used as experimental models in the assessment of pharmacologic agents and the investigation of genetic processes in the cell, including the effects of genetic manipulation.

Third, tissue can be frozen pending characterization with molecular biologic techniques. Transcription, the process by which the genetic code is conveyed to the synthetic apparatus of the cell, and translation, the interpretation of the genetic message and consequent production of specific proteins (Fig. 6 ), can be unravelled by using monoclonal antibodies to recognize protein products and Northern blotting or in situ hybridization with selective radiolabeled gene probes to identify different messenger ribonucleic acid (RNA) chains (Fig. 7).
Histopathologic studies. A number of reports have been generated by this aspect of directional atherectomy. Material excised from primary atherosclerotic lesions in peripheral vessels bore the typical appearance of dense, fibrous plaque with occasional cholesterol crystals. ${ }^{10}$ Two thirds of restenotic lesions in the periphery displayed the characteristic feature of the vascular response to injury, neointimal hyperplasia, but this feature was also found in approximately one third of primary lesions. ${ }^{10,11}$ Coronary artery histologic features were similar; virtually all restenotic lesions revealed neointimal hyperplasia, a feature seen nevertheless in a third of primary lesions. ${ }^{6}$ In our own series neointimal hyperplasia (Fig. 8) indeed correlated significantly with prior intervention, usually conventional balloon angioplasty, and was detected 


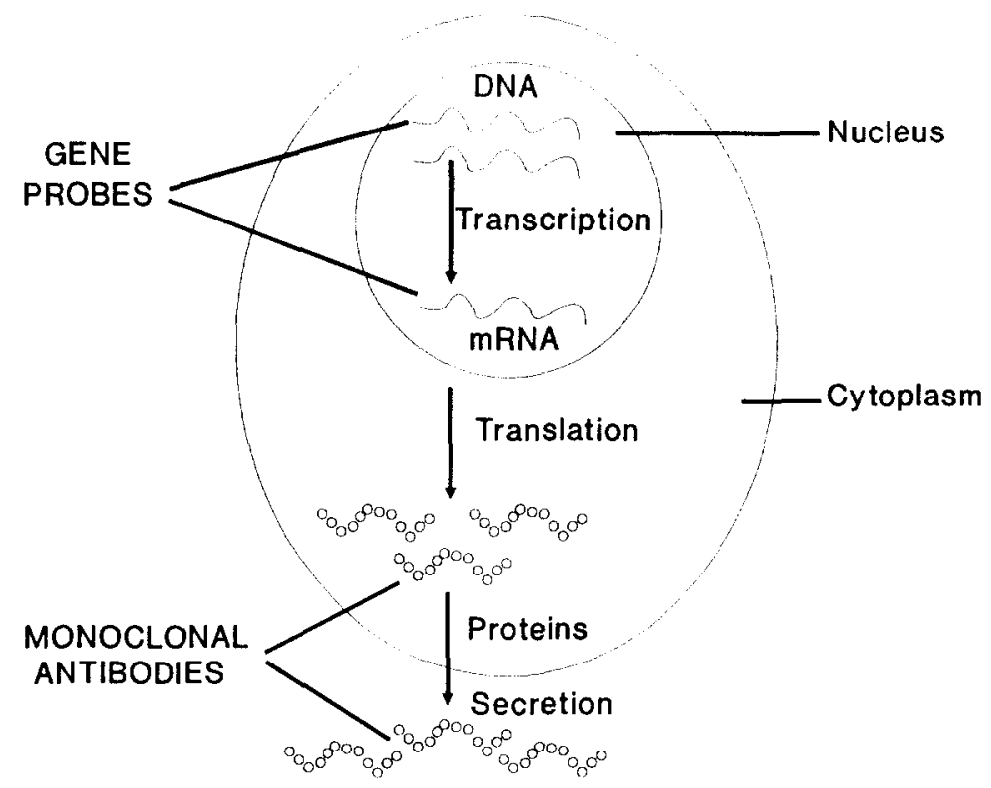

Fig. 6. Diagrammatic representation of route from genomic DNA to protein synthesis. Indicated are points at which different agents act to identify specific processes.

in $20 \%$ of primary lesions (Table 1). The presence of neointimal hyperplasia in a substantial proportion of primary atherosclerotic lesions is consistent with the suggestion that spontaneous intramural injury in the form of plaque rupture occurs commonly, often apparently without serious clinical consequence, ${ }^{12}$ and confirms that the primary atherosclerotic plaque is far from inert. What cannot yet be drawn from the literature is whether or not the primary atherosclerotic plaque demonstrating this evidence of vascular injury can distinguish subgroups of patients with a different pattern of symptoms, rapid onset or crescendo angina pectoris, for example.

Neointimal hyperplasia in plaque tissue testifies to recent or ongoing cellular proliferation. The proliferative status of intimal smooth muscle cells in fresh tissue obtained at directional atherectomy can be documented by using a monoclonal antibody to a cyclin, the proliferating cell nuclear antigen (PCNA), thus identifying cells in the $\mathrm{S}, \mathrm{G}_{1}$, and $\mathrm{G}_{2}$ phases of the cell cycle. ${ }^{13}$ By this means a recent report confirmed that low rates of proliferation do exist in primary atherosclerotic lesions, ${ }^{14}$ in agreement with the histologic data regarding neointimal hyperplasia. In a brief series of patients undergoing directional atherectomy for restenosis in coronary and venous bypass graft stents, compared with patients receiving atherectomy for restenosis postballoon angioplasty, anti-PCNA labeling indicated that smooth-muscle cellular proliferation may wane within a relatively short period of time after coronary interventions: 47 days after stent implantation and 14 days after balloon angioplasty. ${ }^{15}$

There is continuing interest in the role of thrombotic mechanisms in vascular events. In peripheral vessels adherent or incorporated thrombus was a common finding in relation to primary atherosclerotic lesions but less so in relation to restenotic lesions. ${ }^{10,11}$ Although thrombus was not commented on in a report of 73 coronary specimens, ${ }^{6}$ a recent communication described the presence of thrombus in 18 of 19 complex coronary lesions. ${ }^{16}$ Our own group, examining 93 consecutive coronary atherectomy specimens, noted that the presence of organized thrombus within the plaque (Fig. 9) was related to unstable angina (Table I). The proportion of cases was small, $10 \%$, but in these patients the degree of organization of the thrombus allows us to estimate with some confidence that spontaneous plaque rupture took place 7 to 10 days previously. Given accurate clinical details, the comparison of primary atherosclerotic lesions demonstrating either organized thrombus or neointimal hyperplasia, with lesions showing neither of these features, provides fresh insights into the pathophysiologic nature of the plaque in diverse coronary syndromes.

The features of the tissue excised at atherectomy may have further bearing on subsequent clinical outcome. Garratt et al. ${ }^{17}$ examined the depth of resection during coronary atherectomy and related this to the subsequent development of restenosis; deep cuts were suggested to be a risk factor for restenosis in 


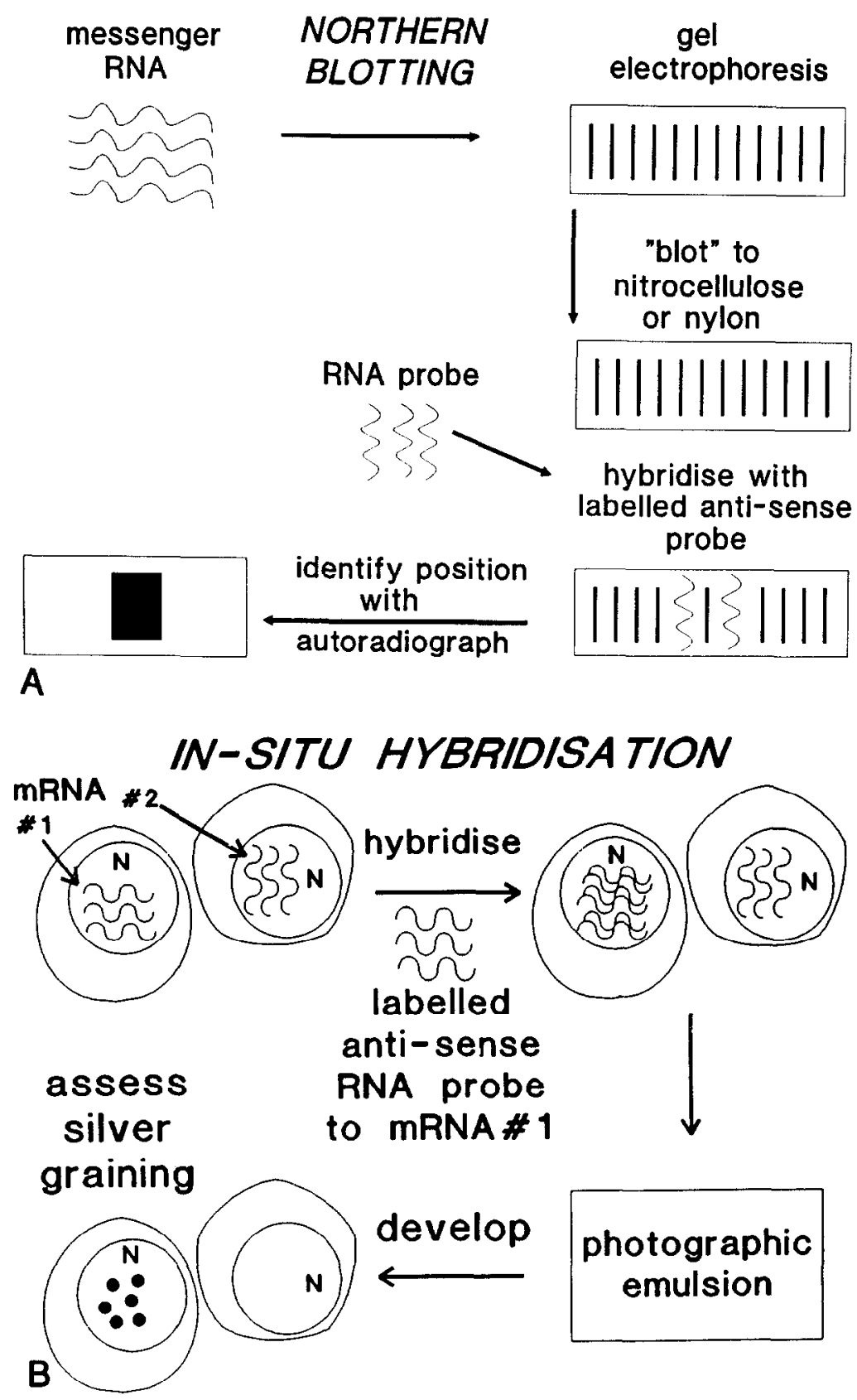

Fig. 7. Diagrammatic representation of techniques of (A) Northern blotting and (B) in situ hybridization.

venous grafts and in already restenotic lesions but not in primary lesions. In material from 125 peripheral and 39 coronary procedures, observation of a highly cellular intima, identification of the internal elastic lamina and the presence of arterial media were found to be predictive of restenosis after atherectomy. ${ }^{18}$ Analysis of specimens from 377 coronary atherectomies revealed that the presence of lesion thrombus and incision into the adventitia were the two factors associated with procedural complications such as vessel occlusion, myocardial infarction, perforation and distal embolization in vein grafts..$^{19}$

Information can also be obtained regarding other forms of vascular intervention. In 33 patients undergoing directional atherectomy for restenosis subsequent to balloon angioplasty, atherectomy, or laser angioplasty, Waller et al. ${ }^{20}$ noted that the histologic appearances were similar regardless of the initial technique. ${ }^{20}$ The enterprising use of directional atherectomy in 21 patients immediately after either 


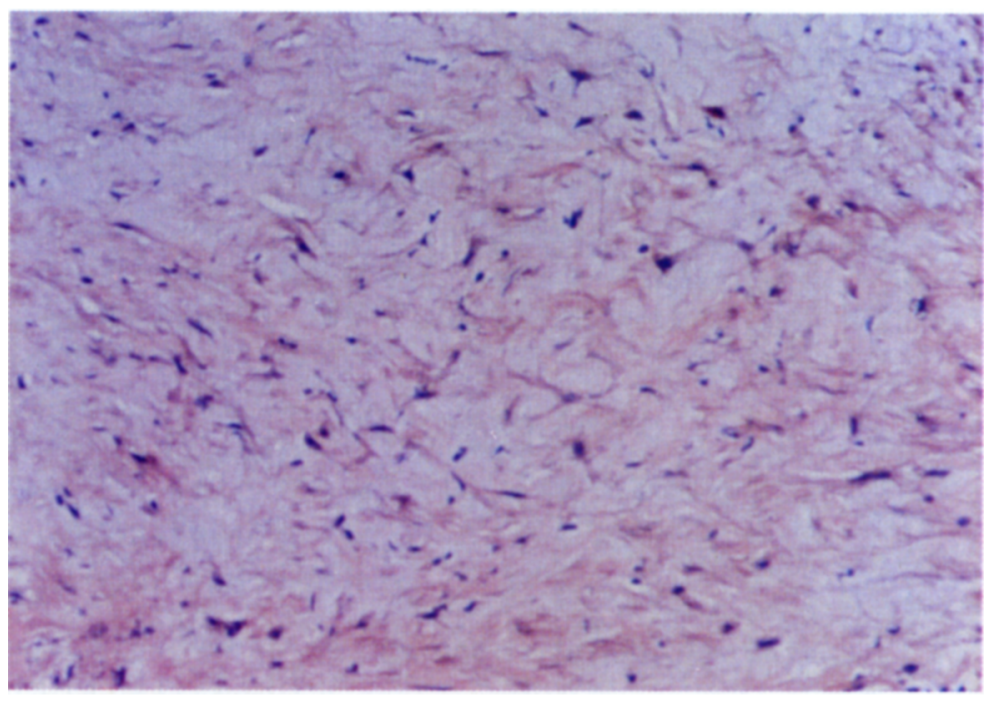

Fig. 8. Section of primary atherosclerotic coronary artery plaque excised at directional coronary atherectomy demonstrating neointimal hyperplasia. (hematoxylin-azofloxin stain; $\times 450$ ).

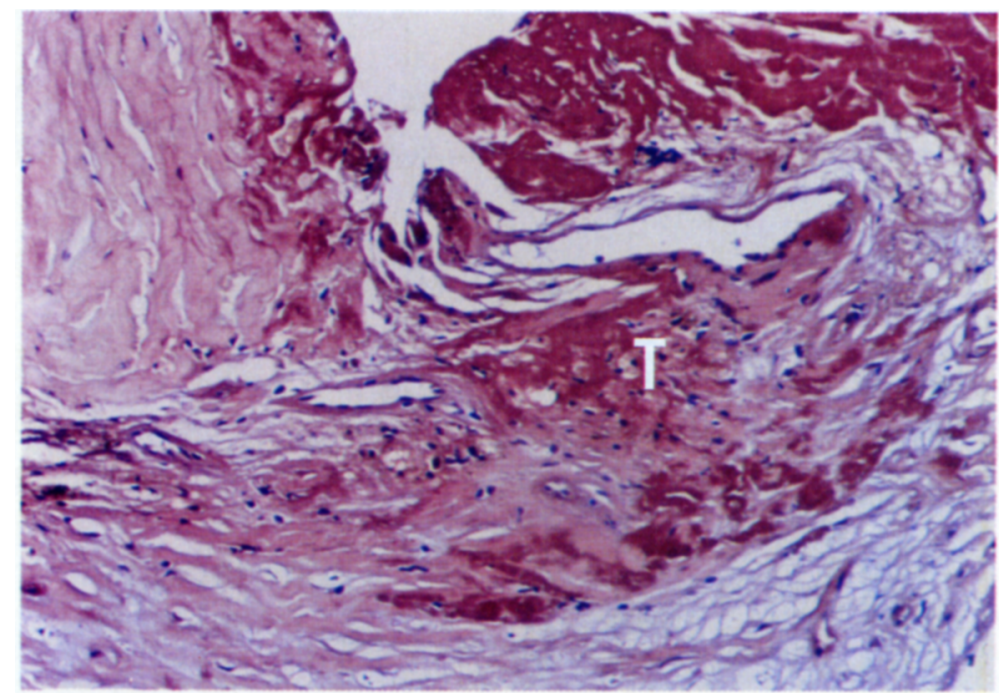

Fig. 9. Section of atherosclerotic coronary artery plaque excised at directional coronary atherectomy demonstrating organized thrombus $(T)$. (hematoxylin-azofloxin stain, $\times 400$ ).

Table I. Frequencies with which neointimal hyperplasia was found in relation to lesion type and organized thrombus was found in relation to symptoms in coronary artery plaque tissue excised from 93 patients at directional atherectomy

\begin{tabular}{lcc}
\hline & Primary lesion & Restenosis \\
\hline Neointimal hyperplasia & $14 / 69(20 \%)$ & $17 / 24(71 \%)$ \\
& $p<0.001, X^{2}$ test \\
& Stable angina & Unstable angina \\
Organized thrombus & $1 / 48(2 \%)$ & $10 / 45(22 \%)$ \\
& $p<0.01, X^{2}$ test \\
\hline
\end{tabular}

Nd:YAG ("hot-tip"), holmium:YAG, or excimer laser angioplasty allowed Isner et al. ${ }^{21}$ to describe the pathologic effects of the three modes of laser, which ranged from charring several cell layers thick with the first to a mildly basophilic, serrated appearance, one cell layer deep with the last. ${ }^{21}$ Findings such as these may be useful when considering both the procedural result and the longer-term outcome of laser thermal and photoablation and may influence changes in clinical practice.

Studies using directional atherectomy are enhanced by the use of quantitative angiography where 
edge-detection analysis in particular provides useful information on plaque geometry in relation to both the effect of the procedure ${ }^{22}$ and histopathologic data. Conceptually, the marriage of directional atherectomy and intravascular ultrasonography is very attractive. High-quality images of the vessel wall will help to assess the separate contributions of the three modes of action of the atherectomy device: the "Dotter" effect, the effect of balloon inflation, and the effect of the cutter. Also, examination of tissue retrieved may prove useful in corroborating the information provided by intravascular ultrasonography with regard to the components and architecture of the vessel wall. In a similar manner, different types of thrombus, or features of the plaque such as fissuring, revealed by angioscopy, can be sought in atherectomy samples.

Cell and cell culture studies. Bauriedel et al..$^{23}$ were the first to embark on cell-based investigations with atherectomy material and demonstrated that cells disaggregated from atherectomy specimens could be identified as smooth-muscle cells by their staining with monoclonal antibodies to smooth-muscle cell alpha-actin. ${ }^{23}$ An extension to this work included electron microscopic and electrophoretic studies of peripheral arterial atherosclerotic material. ${ }^{24}$ The mixed phenotype of the intimal smooth-muscle cells (Fig. 5), revealed by the presence of peripheral myofilaments together with dense perinuclear organelles, was consistent with the findings of studies of vascular injury in experimental animal models, and the distribution of cytoskeletal proteins, predominantly beta-, alpha- and gamma-actin and vimentin was similar to that found in studies of surgically excised human tissue. Immunofluorescence microscopy applied to sections of tissue obtained from coronary arteries at atherectomy revealed that vimentin-positive smooth-muscle cells of synthetic phenotype were also positive for cytokeratins 8 and 18. ${ }^{25}$ Cytokeratins are proteins found in fetal and neonatal but not adult vascular smooth-muscle cells, indicating that a subset of the coronary lesion smoothmuscle cells in this study had the characteristics of immature, dedifferentiated cells commonly associated with proliferative properties.

The material obtained at directional atherectomy can be exploited by using the technique of cell culture in the further use and investigation of the small pieces of tissue retrieved. Bauriedel et al. ${ }^{23}$ were also the first to describe the cultivation of fibroblast-like cells from atherectomy tissue explants. ${ }^{23}$ It was subsequently reported that cells isolated from primary atherosclerotic and restenosing lesions in both peripheral and coronary arteries behaved differently in
Table II. Migratory velocity of smooth-muscle cells cultured from primary and restenotic coronary and peripheral arterial lesions excised at directional atherectomy

\begin{tabular}{cc}
\hline Cell source & Migratory velocity \\
\hline Primary & \\
Coronary & $19.4 \pm 5.1(n=7)$ \\
Peripheral & $21.1 \pm 2.5(n=12)$ \\
Restenotic & \\
Coronary & $46.2 \pm 3.6(n=5)$ \\
Peripheral & $48.0 \pm 3.0(n=6)$ \\
\hline
\end{tabular}

Values are expressed as mean \pm SEM. Units are $\mu \mathrm{m} / \mathrm{hr}$ (adapted from Bauricdel G, et al. Circulation 1992;85:554 64).

initial cell culture and early subculture. ${ }^{26,}{ }^{27}$ Restenosis cells demonstrated more rapid growth, attributed to a significant subpopulation of small, low-adhesive proliferative cells that featured less among the cells of primary atherosclerotic origin. Two other findings were of particular interest. First, primary cells in culture did not respond to platelet-derived growth factor (PDGF), whereas restenosis cells responded by increasing their growth. Second, primary lesion cells proliferated in response to medium conditioned by restenosis cells, allowing the authors to propose an autocrine growth-promoting (non-PDGF) function of smooth-muscle cells in restenosis lesions in human beings, a mechanism previously suggested in animal studies. In a more recent study, this group describes their examination of cells cultivated from peripheral and coronary primary atherosclerotic and restenotic lesions by using a computer-assisted cell motion analysis system. ${ }^{5}$ Cell oulgrowth was not related to any clinical parameter, including the type of lesion, but restenosis cells were found to display increased migratory activity during initial outgrowth in culture (Table II), which in conjunction with their earlier findings regarding proliferation, led the authors to emphasize the importance of these aspects of cell behavior in the restenosis process.

Our own group has also sought to use initial and extended cell culture as a means of examining the behavior of human coronary smooth-muscle cells obtained at directional atherectomy. Confluent cells cultured from retrieved tissue and electron micrographic images of these cells reveal appearances consistent with a mixed contractile/synthetic phenotype (Fig. 10). In agreement with the report of Dartsch et al. ${ }^{26}$ with respect to peripheral vascular lesions, we found that smooth-muscle cells cultured from restenotic coronary lesions demonstrated accelerated growth compared with cells from primary atherosclerotic coronary lesions that had a growth pattern similar to young control human umbilical artery medial 


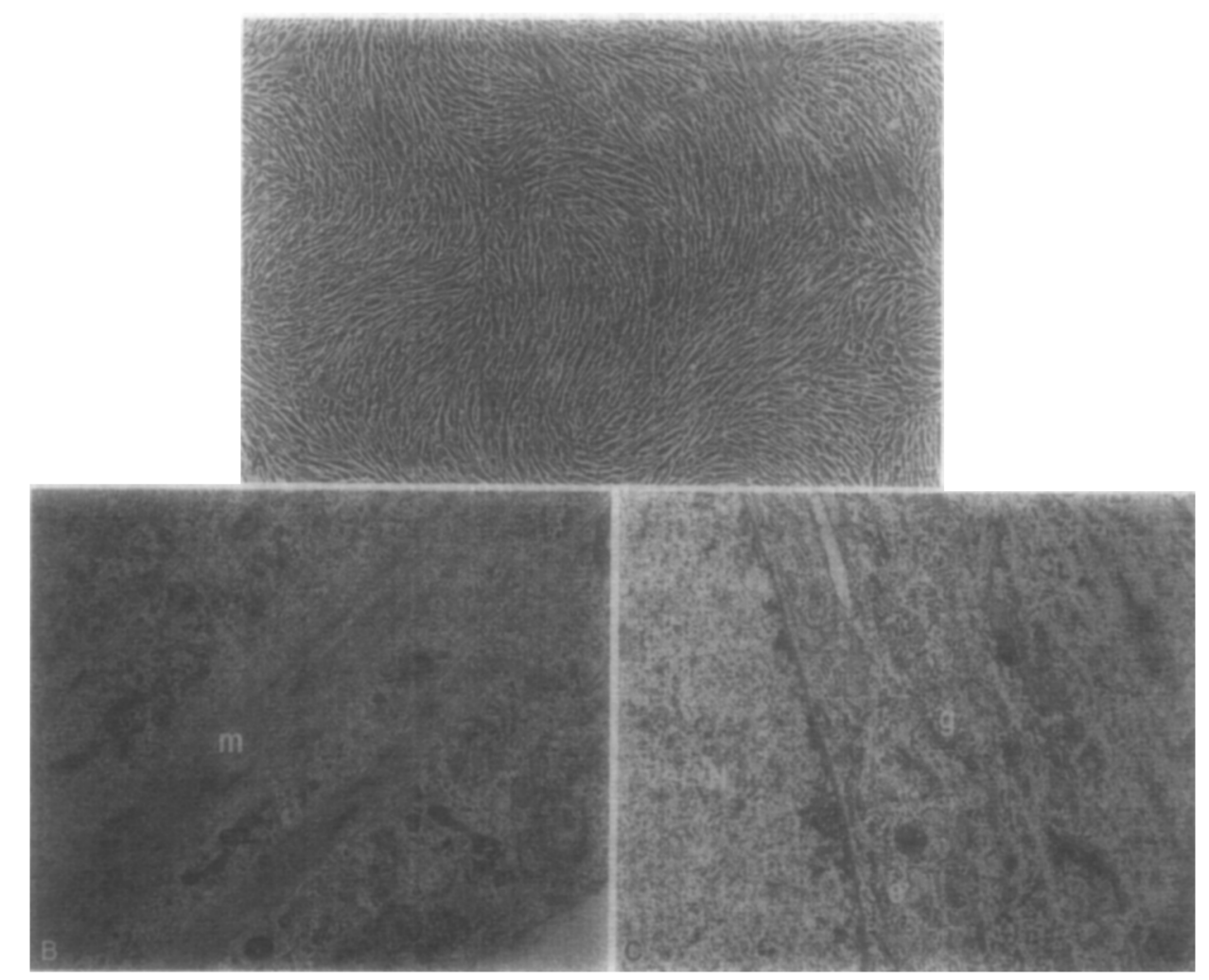

Fig. 10. A, Confluent cultured cells derived from tissue retrieved at directional coronary atherectomy; typical "hill-and-valley" culture morphologic features. Electron microscopic features of smooth-muscle cells from coronary artery atherosclerotic plaque tissue excised at directional atherectomy. B, peripheral myofibrils $(m)$. C, perinuclear $(N)$ organelles, endoplasmic reticulum $(e)$, golgi bodies $(g)$, and numerous ribosomes are visible.

cells (Fig. 11). Although we were also unable to relate growth in culture to any clinical parameter, a factor favoring successful initial smooth-muscle cell outgrowth was the presence of organized thrombus in the atherectomy specimen (Table III), hinting at links between complex lesions, unstable angina, and restenosis. Further, coronary cells derived from both types of lesion demonstrated increased extracellular matrix production compared with the umbilical artery cells ${ }^{27}$ (Table IV), consistent with the concept that extracellular matrix synthesis is a property of the adult vascular smooth-muscle cell important in both primary atherosclerosis and restenosis.

Cultured human vascular cells provide us with new alternative experimental models for the assessment of the in vitro actions of existing therapies and, potentially, for the development of novel treatment strategies. Having previously noted that material retrieved from patients receiving angiotensin-converting enzyme inhibitors was less likely to demonstrate successful smooth-muscle cell outgrowth, ${ }^{29}$ Bauriedel et al. ${ }^{30}$ showed recently by means of cell motion analysis and cell population doubling times that two aspects of smooth-muscle cell growth in culture, migration, and proliferation responded similarly but to different extents to a variety of exogenous pharmacologic agents. The combination of photosensitizing hematoporphyrin derivatives and photoradiation, a potential means of localizing and attacking the atherosclerotic plaque, has been examined by using smooth-muscle cells cultured from tissue retrieved during peripheral arterial atherectomy. ${ }^{31}$ These cells were found to be more susceptible to damage than control vascular smooth-muscle cells cultured from healthy arteries biopsied postmortem. Cell-culture models need not be restricted to monolayers of one particular cell type. Coculture systems, as recently reviewed by Betz, ${ }^{32}$ can be constructed to mimic the vessel wall and thus cater for important interactions such as those that occur between the endothelium and the media.

"Gene therapy", ${ }^{33}$ whereby new genetic material is introduced to the cell by using methods such as lipofection, ${ }^{34}$ retroviral vectors, ${ }^{35}$ engineered cells, ${ }^{36,37}$ and even particle bombardment, ${ }^{38}$ is a source of considerable current interest. Cells in culture may be 
Table III. Frequency of smooth-muscle cell outgrowth in 98 attempted cultures in relation to presence of organized thrombus in coronary artery plaque tissue excised at directional atherectomy

\begin{tabular}{ccc}
\hline & Thrombus & No thrombus \\
\hline SMC outgrowth & $8 / 10(80 \%)$ & $35 / 88(40 \%)$ \\
& $p<0.025, X^{2}$ test \\
\hline
\end{tabular}

Table IV. Extracellular matrix production of collagen and sulphated-glycosaminoglycans of human coronary cells cultured from plaque tissue excised at directional atherectomy and of smooth muscle cells cultured from media of human umbilical arteries

\begin{tabular}{lcc}
\hline Cell source & Collagen & Glycosaminoglycans \\
\hline Restenosis & $0.034 \pm 0.006^{1}$ & $11.5 \pm 1.1^{3}$ \\
Primary & $0.033 \pm 0.004^{2}$ & $15.4 \pm 3.1^{4}$ \\
Umbilical & $0.019 \pm 0.004^{1,2}$ & $5.4 \pm 1.0^{3,4}$ \\
\hline
\end{tabular}

Collagen synthesis was determined by the uptake of tritiated proline and sulphated-glycosaminoglycan synthesis by the incorporation of ${ }^{35}$ sulphate. Values are nanomols of ligand per microgram of total protein, mean \pm SEM; ${ }^{1-3} \mathrm{p}<0.05,{ }^{4} p<0.005$.

used to evaluate the success and effects of attempts to modify the genome and influence translation and transcription; human vascular cells obtained at atherectomy are a logical preliminary testing ground.

Frozen tissue studies. The recent publication of Leclerc et al. ${ }^{39}$ focuses on transcription (Fig. 6) and reports the increased expression of messenger RNA for nonmuscle myosin heavy chain-B (MHC-B) in the intimal smooth-muscle cells of restenosis tissue compared with primary atherosclerotic tissue retrieved at peripheral or coronary atherectomy. ${ }^{39}$ This finding is of interest because nonmuscle myosin has been implicated in vascular smooth-muscle cell division and proliferation; the method is a timely reminder of the application of molecular biologic techniques in clinical science. The mRNA for MHC-B was detected by in situ hybridization (Fig. 7) by using an antisense complementary (c)RNA probe prepared from recently cloned complementary deoxynibonucleic acid (DNA) coding for an isoform of the human nonmuscle MHC-B gene. To control for the specificity of the antisense cRNA probe, parallel hybridizations were performed with the sense cRNA probe; to control for cross-hybridization of the nonmuscle myosin probe to smooth-muscle myosin, hybridizations were performed in normal human internal mammary artery media preparations. By using a similar technique, this research group has now in-

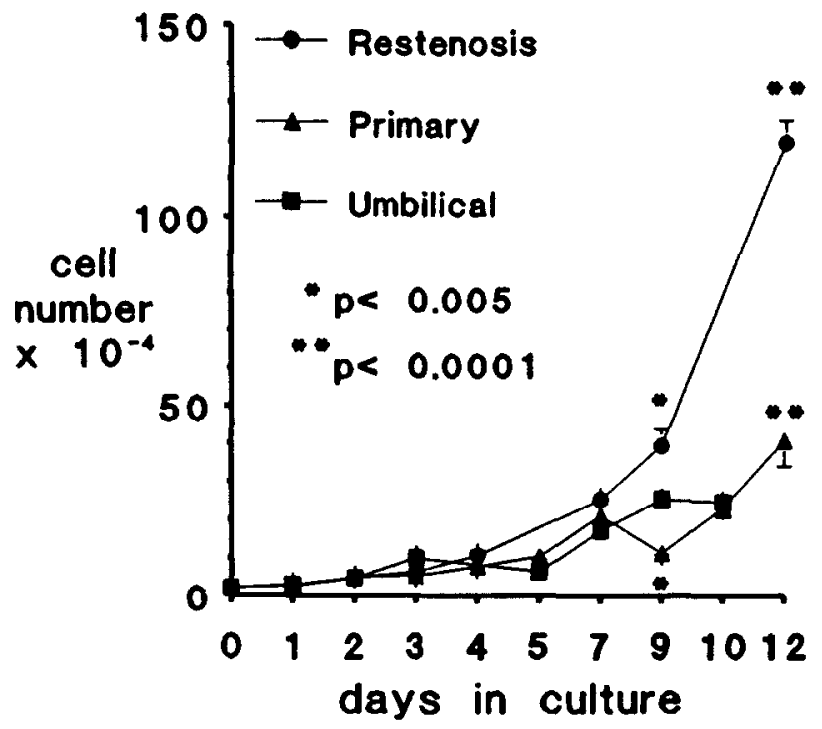

Fig. 11. Growth curves of smooth-muscle cells derived from human coronary restenotic and primary atherosclerotic lesions and from normal human umbilical artery media in secondary culture.

vestigated the possible role of transforming growth factor- $\beta$ ('TGF- $\beta$ ) and suggests that it may be involved in vascular restenosis. ${ }^{40}$ Work of this nature, probing genetic regulation in plaque tissue, has particular relevance in view of the possibilities of gene therapy. However, on a note of caution, as the number of growth factors and other mediators implicated in atherogenesis and restenosis expands the difficulty of interpreting this newfound knowledge of the cell renders the choice of optimal targets less straightforward.

\section{PROSPECTS}

The various research techniques we have mentioned are unlikely to excite the cell biologist, who is well acquainted with them. However, with the advent of directional atherectomy, it is now possible to apply such techniques in a systematic manner to the investigation of atherosclerosis, our most common source of mortality, and restenosis, the response to injury that besets vascular intervention, by using human material. The identification of pathophysiologic mechanisms within the cell holds out the prospect of discovering, developing, and testing new pharmacologic or genetic therapies that can then be assessed in human cell culture systems. Work of this nature represents an important advance at a time when, in the field of restenosis, the failure of both empiric drug trials and trials based on apparently sound animal experimental evidence is a cause of concern. ${ }^{41,42}$ Directional atherectomy opens up new 
avenues of research, but it falls to the interventionalist to generate the enthusiasm among colleagues in the basic sciences that is the stimulus for fresh collaborative research.

\section{REFERENCES}

1. Simpson JB, Johnson DE, Thapliyal HV, Marks DS, Braden LJ. Transluminal atherectomy: a new approach to the treat. ment of atherosclerotic vascular disease. Circulation 1985 72:III-146.

2. Simpson JB, Selmon MR, Robertson GC, Cipriano PR, Hayden WG, Johnson DE, Fogarty TJ. Transluminal atherectomy for occlusive peripheral vascular disease. Am J Cardiol 1988, 61:96-101G

3. Hofling B, von Polnitz A, Backa D, von Arnim T, Lauterjung I, Jauch KW, Simpson JR. Percutaneous removal of atheromatous plaques in peripheral arteries. Lancet 1988;1:384-6.

4. Hinohara T, Selmon MR, Robertson GC, Braden L, Simpson JB. Directional atherectomy. New approaches for treatment of obstructive coronary and peripheral vascular disease. Circulation 1990;81:IV79-91.

5. Bauriedel G, Windstetter U, DeMaio SJ, Kandolf R, Hofling B. Migratory activity of human smooth muscle cells cultivated from coronary and peripheral primary and restenotic lesions removed by percutaneous atherectomy. Circulation 1992; 85:554-64.

6. Safian RD, Gelhfish JS, Frny RF, Schnitt S.J, Schmidt DA Baim DS. Coronary atherectomy. Clinical, angiographic and histological findings and observations regarding potential mechanisms. Circulation 1990;82:69-79.

7. Graor RA, Whitlow PL. Transluminal atherectomy for occlusive peripheral vascular disease. J Am Coll Cardiol 1990; 15:1551-8.

8. Hinohara T, Rowe MH, Robertson GC, Selmon MR, Braden L, Leggett JH, Vetter JW, Simpson JB. Effect of lesion characteristics on outcome of directional coronary atherectomy. .J Am Coll Cardiol 1991;17:1112-20

9. Campbell GR, Campbell JH. Smooth muscle phenotypic changes in arterial wall homeostasis. Implications for the pathogenesis of atherosclerosis. Exp Mol Pathol 1985;42:13962.

10. von Polnitz A, Nerlich A, Berger H, Hofling B. Percutaneous peripheral atherectomy: angiographic and clinical follow-up of 60 patients. J Am Coll Cardiol 1990;15:682-8.

11. Johnson DE, Hinohara T, Selmon MR, Braden LJ, Simpson JB. Primary peripheral arterial stenoses and restenoses excised by transluminal atherectomy: a histopathologic study. $f$ Am Coll Cardiol 1990;15:419-25.

12. Davies MJ, Thomas AC. Plaque fissuring: the cause of acute myocardial infarction, sudden ischaemic death and cescendo angina. $\mathrm{Br}$ Heart $\mathrm{J}$ 1985;53:363-73.

13. Gordon D, Reidy MA, Benditt EP, Schwartz SM. Cell proliferation in human coronary arteries. Proc Nat Acad Sci US A $1990 ; 87: 4600-9$.

14. O'Brien E, Gordon D, Yoon S, Schwartz S, Stewart D. Cell proliferation in primary and restenotic human coronary atherosclerosis. J Am Coll Cardiol 1992;19:328A.

15. Strauss BH, Umans VA, van Suylen RJ, de Feyter PJ, Marco J, Robertson GC, Wijns W, Vuzevski VD, Bosman FT, Serruys PW. Directional coronary atherectomy for treatment of restenosis within coronary stents. Clinical, angiographic and histologic results. J Am Coll Cardiol 1992;20:1465-73.

16. Christou CP, Haft JI, Goldstein JE, Carnes RE. Histopathological correlation of coronary arteriographic lesion morphology using directed atherectomy derived specimens: frequent thrombus in complex lesions. J Am Coll Cardiol 1992;19:375A.

17. Garratt KN, Holmes DR, Bell MR, Bresnahan JF, Kaufmann UP, Vlietstra RE, Edwards WD. Restenosis after directional coronary atherectomy: differences between primary athero- matous and restenosis lesions and influence of subintimal tis sue resection. J Am Coll Cardiol 1990;16:1665-71

18. Backa D, Nerlich A, Mack B, Hofling B. Histological predic tors for restenoses after vascular interventions in primary ar teriosclerotic lesions. J Am Coll Cardiol 1992;19:170A.

19. Johnson D, Hinohara T, Robertson G, Selmon M, Braden L, Simpson J. Acute complications of directional coronary atherectomy are related to the morphology of excised stenoses. . Am Coll Cardiol 1992;19:76 A.

20. Waller BF, Pinkerton CA, Rohbaum DA, Linnemeier TJ, Orr CM, van Tassel JW, Slack JD. Restenosis tissue following hot-tip laser, excimer laser, primary atherectomy and balloon angioplasty procedures: histologically similar intimal proliferation in $3: 3$ atherectomy patients. Circulation 1990;82:III312.

21. Isner JM, Rosenfield K, Kearney M, White C, Ramee S, Langevin $\mathrm{E}$, Razvi S. In vivo assessment of acute tissue injury resulting from laser irradiation in humans: histologic analysis of specimens obtained from 21 patients by directional atherectomy immediately following laser angioplasty. Circulation 1991;84:II-724.

22. Serruys PW, Umans VAWM, Strauss BH, van Suylen RJ, van den Brand M, Suryapranata H, de Feyter PJ, Roelandt J. Quantitative angiography after directional coronary atherectomy. Br Heart. J 1991;66:122-9.

23. Bauriedel G, Dartsch PC, Voisard R, Roth D, Simpson JB, Hofling B, Betz. E. Selective percutaneous biopsy of atheromatous plaque tissue for cell culture. Basic Res Cardiol 1989; 84:326-31

24. Dartsch PC, Bauriedel G, Schinko I, Weiss HD, Hofling B, Betz E. Cell constitution and characteristics of human ath crosclerotic plaques selectively removed by percutaneous atherectomy. Atherosclerosis 1989;80:149-57.

25. Jahn L, Kreuzer J, von Hodenberg E, Allenberg J, Reis GJ. Cytokeratins 8 and 18 are synthesized in smooth muscle cells of atherosclerotic plaques regardless of the site of the lesion. Circulation 1991;84:II-343

26. Dartsch PC, Voisard R, Bauriedel G, Hofling B, Betz E. Growth characteristics and cytoskeletal organization of cultured smooth muscle cells from human primary stenosing and restenosing lesions. Arteriosclerosis 1990;10:62-75.

27. Dartsch PC, Voisard R, Betz E. In vitro growth characteristics of human atherosclerotic plaque cells: comparison of cells from primary stenosing and restenosing lesions of peripheral and coronary arteries. Res Exp Med 1990;190:77-87.

28. Strauss BH, van Hooije CM, de Jong M, Verkerk A, Jongkind JF, van der Giessen WJ, MacLeod DC, Serruys PW. Human coronary smooth muscle cells in culture: phenotypic features and extracellular matrix production. Circulation 1991;84:1I295.

29. Bauriedel G, Windstetter $\mathrm{U}$, Kandolf R. Cell culture of human coronary and peripheral atherectomy specimens: determinants and perspectives. Circulation 1991:84:II-296.

30. Bauriedel C, Ganesh S, Heidemann P, Heimerl I, DeMaio S, Kandolf R, Hofling B. Concordant anti-proliferative and anti-migratory effects of cardiovascular drugs on human plaque smooth muscle cells. J Am Coll Cardiol 1992;19:30A.

31. Dartsch PC, Ischinger T, Betz E. Responses of cultured smooth muscle cells from human nonatherosclerotic arteries and primary stenosing lesions after photoradiation: implications for photodynamic therapy of vascular stenoses. J Am Coll Cardiol 1990:15:1545-50.

32. Betz E. Cell culture systems to study progression and inhibition of intimal proliferations. Basic Res Cardiol 1991;86:79-86

33. Nabel EG, Plautz G, Nabel GJ. Gene transfer into vascular cells. J Am Coll Cardiol 1991;17:189-94B.

34. Felgner PL, Gadek TR, Holm M, Roman R, Chan HW, Wenz M, Northrop .JP, Ringold GM, Danielsen M. Lipofection: a highly efficient, lipid-mediated DNA-transfection procedure. Proc Nat Acad Sci U S A 1987;84:7413-7.

35. Flugelman MY, Jaklitsch MT, Newman KD, Casscells W, 
Bratthauer GL, Dichek DA. Low level in vivo gene transfer into the arterial wall through a perforated balloon catheter. Circulation 1992;85:1110-7

36. Nabel EG, Plautz G, Boyce FM, Stanley JC, Nabel GJ. Recombinant gene expression in vivo within endothelial cells of the arterial wall. Science 1989;244:1342-4.

37. Plautz G, Nabel EG, Nabel GJ. Introduction of vascular smooth muscle cells expressing recombinant genes in vivo. Circulation 1991;83:578-83.

38. Williams RS, Johnston SA, Riedy M, de Vit MJ, McElligott $\mathrm{SG}$, Sanford JC. Introduction of foreign genes into tissues of living mice by DNA-coated microprojectiles. Proc Nat Acad Sci USA 1991;88:2726-30.

39. Leclerc G, Isner JM, Kearney M, Simons M, Safian RD, Baim
DS, Weir L. Evidence implicating nonmuscle myosin in restenosis. Use of in situ hybridisation to analyze human vascular lesions obtained by directional atherectomy. Circulation 1992;85:543-53.

40. Nikol S, Isner J, Pickering G, Kearney M, Leclerc G, Weir L. Transforming growth factor beta-1: a peptide growth factor with increased expression in vascular restenosis. J Am Coll Cardiol 1992;19:329A

41. Muller DWM, Ellis SG, Topol EJ. Experimental models of coronary artery restenosis. J Am Coll Cardiol 1992;19:418-32

42. Ferrell M, Fuster V, Gold HK, Chesebro JH. A dilemma for the 1990s. Choosing appropriate experimental animal model for the prevention of restenosis. Circulation 1992;85:1630-1. 